\title{
Comparison Of Precooled Tetrafluoroethane Versus Lidocaine Topical Anesthetic As A Pre- Injection Anesthetic For Inferior Alveolar Nerve Block- A Split Mouth Study
}

\author{
Research Article
}

Vivek D. Menon ${ }^{1}$, M R Muthusekhar ${ }^{2 *}$

${ }^{1}$ Saveetha Dental College and Hospitals, Saveetha Institute of Medical and Technical Sciences (SIMATS), Saveetha University, Chennai 600077, Tamil Nadu, India.

${ }^{2}$ Professor and Head of Department, Saveetha Dental College and Hospitals, Saveetha Institute of Medical and Technical Sciences (SIMATS), Saveetha University, Chennai 600077, Tamil Nadu, India.

Abstract

Background: Dental anxiety and fear of needle injection is one among the foremost common problems encountered by dental practitioners. This might affect the patient's quality of life. Several methods are suggested to lower the discomfort of local anaesthesia injection during dental procedures. Numbness of injection site is one among the recommended strategies. Materials and Methods: During this Split Mouth design study, a complete of 60 healthy patients between the age of 18 and above were selected and were randomly divided into two equal groups. Sixty participants (120 sites) undergoing prophylactic orthodontic extraction received a five second application of a refrigerant (tetrafluoroethene, sixty sites) and a two minute application of a local anaesthetic ( $2 \%$ percent lidocaine, sixty sites) before an injection of an area anaesthetic solution was administered with a 30 gauge needle. Participants rated the pain they experienced after each injection by employing a 100-millimetre visual analogue scale (VAS). The pain was calculated by measuring the space in millimetres from the no pain end of the scale (VAS scale).

Results: The means of visual analogue scales (VAS) for the study and control groups were $42.20 \pm 12.70$ and $58.40 \pm 16.83$, respectively; With statistically significant differences between the 2 groups $(\mathrm{P}<0.05)$.

Conclusion: The utilization of a precooled refrigerant was simpler compared with lidocaine local anaesthetic in reducing the pain experienced by participants who received inferior alveolar nerve blocks.

Keywords: Cooling; Topical Anaesthesia; Pain Perception.

\section{Introduction}

Needle injection of a local anaesthetic may induce fear and anxiety to some patients, especially during dental procedures. The sensation of a needle being attached to a syringe and penetrating the oral mucosa is sort of distressing and carries a negative impact on a patient's psychology [1]. Research has shown that most of the patients postpone their dental visits primarily thanks to the fear of needles, pain and biting injury from injection [2].

Poor pain control alongside the fear and anxiety of the needle might interfere with appropriate dental management. So, profound local anaesthesia is critical, and several other methods are introduced to scale back pain during injection like applying topical anaesthetics pastes, warming or buffering the local anaesthetic agents, and slow inflation of local anaesthetics [3]. Furthermore, some studies have focused on cooling the injection site for better pain relief before or after local anaesthetic injection [4].

Also, vibration or pressure to the injection site by high-tech mechanical delivery systems has been tried out recently. Topical anaesthetic agents are common to use before local anesthesia injection [5]. They are presented in various chemical bases with different potent and clinical indication; Therefore, toxic sequels thanks to over absorption by mucosa can't be prohibited [6]. Also, dissolution of those topical agents with saliva can impose negative impact on its anaesthetic efficacy [7].

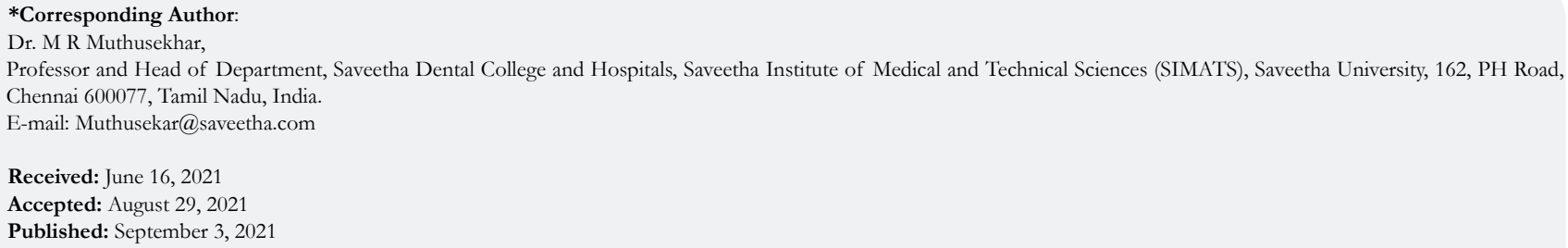


Previously our team has a rich experience in working on various research projects across multiple disciplines [8-22]. Now the growing trend in this area motivated us to pursue this project.

\section{Materials and Methods}

A total of 60 healthy adults with no history of systemic diseases (ASA Grade I status) and with non-allergic history to local anesthesia within the age above 18 years were selected from the outpatient clinics within the department of Oral and Maxillofacial Surgery at Saveetha Dental College Dental and Hospital, Chennai, Tamil Nadu . It was a split mouth randomized study, so patients requiring bilateral local anaesthetic block (bilateral inferior alveolar nerve block)for any patients undergoing prophylactic orthodontic extraction. Selected patients were then randomly divided into two equal groups (groups I and II) having 60 sites in each group. Randomization was done using the pc generated random equal numbers of blinded packages containing either of the group code. Blinded packages were prepared by the nonclinical staff consistent with the generated random chart and were available to the investigator only after the patient was recruited for the study. Once the group was selected, the sites for the application of local anaesthetic agents and precooling agents were selected randomly by coin toss method and therefore the selected sites were then named as site A and site B for his or her respective groups. Five Second application of a refrigerant (tetrafluoroethene, sixty sites) and a two-minute application of a local anaesthetic $(2 \%$ percent lidocaine, sixty sites) before an injection of an area anaesthetic solution was administered with a 30 gauge needle. During the insertion of the needle, the patient's pain perception was analysed using visual analogue scale (VAS) by the operator. The statistical analysis was done using Statistical Package for Social Sciences (SPSS) Version 15.0 Statistical Analysis Software. The values were represented in mean $\pm \mathrm{SD}$.

\section{Results}

The research comprised 60 patients (28 Males and 32 Females) with a mean age of $26.94 \pm 0.76$ years).

ANALYSIS OF VAS SCALE: The means of VAS values for the study and control groups were $42.20 \pm 12.70$ (range: 0-100) and
$58.40 \pm 16.83$ (range: $0-100$ ), respectively with statistically significant lower VAS scores within the study group $(\mathrm{P}<0.05)$. The Figure 2 describes the vas score results.

\section{Discussion}

The aim of the study was to determine the effectiveness of a topical refrigerant compared with lidocaine topical anaesthetic in reducing the pain experienced during an inferior alveolar nerve block. The results showed use of a precooled refrigerant was simpler compared with lidocaine local anaesthetic in reducing the pain experienced by participants who received inferior alveolar nerve blocks.

The results of this study correspond with the study administered on cooling the skin before surgery of inguinal hernias, Chan et al, used a laser system with a cooling device to treat 37 patients with nevus of Ota removal [8]. They reported that cooling the location of injection resulted in less pain perception by their patients. However, the difference wasn't statistically significant and that they didn't specify the target criteria to evaluate pain. Also, we should always consider that the pain induced by laser therapy may differ from that of local anaesthesia.

The findings of Leff et al.'s study is according to the results of this study [9]. Furthermore, Kuwahara and Skinner and Goel et al, in several studies, reported reduction in pain perception by application of ice on injection site [10].The results of this study support the results reported by Harbert, who applied ice to scale back pain perception related to palatal injections. However, his study was not a randomized control trial, and he did not support his results with objective pain scoring systems. The results of this study are in accordance with the findings obtained by the study of Kosaraju et al., but their evaluation were not elaborated on an objective scale. That is difficult to gauge a sense like pain perception precisely just using the subjective scale (VAS) for assessment [11]. Aminabadi et al, reported the efficacy of 2 min application of ice before inferior alveolar nerve block injection in decreasing perception of pain. The finding would be more reliable if each single subject has been considered to be as a case and control simultaneously [12]. Several theories are suggestingelucidating the mechanism of effect of injuries and induction of analgesia at an area level, which include decreasing tissue rate and vasoconstriction re-

Figure 1

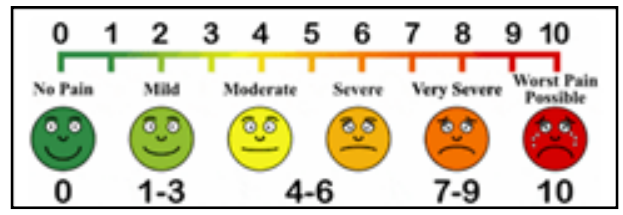

Figure 2
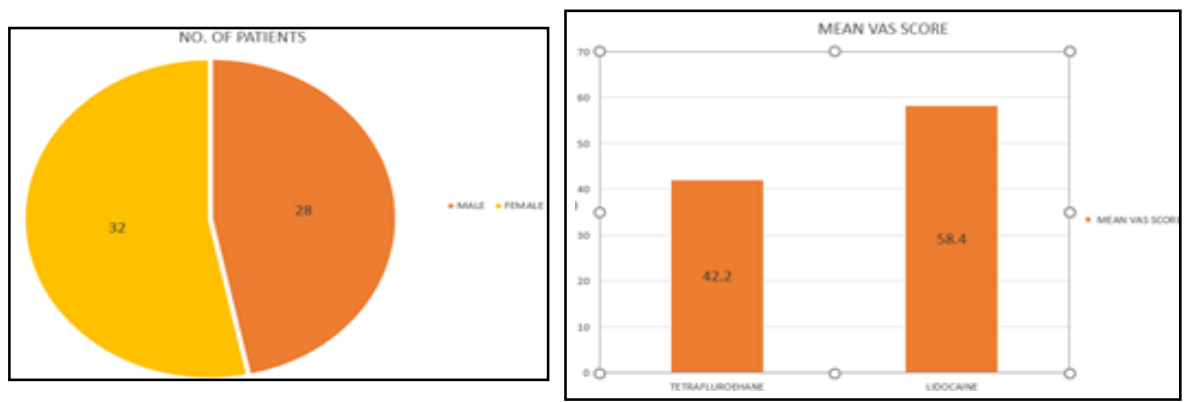
sulting in a decrease within the inflow of inflammatory mediators and a decrease in oedema [13]. This might explain the successful application of topical cooling to scale back bruising, bleeding, and oedema in sports injuries and after orthopaedic surgeries.

Local cooling is additionally believed to slow or eliminate pain signal transmission and to retard neuromuscular transmission. Additionally, cooling muscle tissue reduces its tone via a discount within the activity of muscular spindles [14]. Topical cold application stimulates myelinated A fibres, activating inhibitory pain pathways, which successively raises absolute threshold. Cold has also been demonstrated to figure at the spinal level to inhibit myotatic reflex and reduce spasm [15].

The results of this study support the thought that topical cooling amplifies absolute threshold to stimuli like needle stick during local anaesthetic injection and helps patient management during dental procedures.

Our institution is passionate about high quality evidence based research and has excelled in various fields [31-40].

\section{Conclusion}

The use of a precooled refrigerant was simpler compared with lidocaine local anaesthetic in reducing the pain experienced by participants who received inferior alveolar nerve block.

\section{References}

[1]. Tellez M, Potter CM, Kinner DG, Jensen D, Waldron E, Heimberg RG, et al. Computerized tool to manage dental anxiety: a randomized clinical trial. J. Dent. Res. 2015 Sep;94(9_suppl):174S-80S.

[2]. De Stefano R, Bruno A, Muscatello MR, Cedro C, Cervino G, Fiorillo L. Fear and anxiety managing methods during dental treatments: a systematic review of recent data. Minerva Stomatol. 2020 Dec 1;68(6):317-31.

[3]. Munshi AK, Hegde A, Bashir N. Clinical evaluation of the efficacy of anesthesia and patient preference using the needle-less jet syringe in pediatric dental practice. J Clin Pediatr Dent. 2001 Winter;25(2):131-6.Pubmed PMID: 11314212

[4]. Malamed SF, Falkel M. Buffered local anaesthetics: the importance of $\mathrm{pH}$ and CO2. SAAD digest. 2013 Jan 1;29:9-17.

[5]. Al-Melh MA, Andersson L. Comparison of topical anesthetics (EMLA/Oraqix vs. benzocaine) on pain experienced during palatal needle injection. Oral Surg Oral Med Oral Pathol Oral Radiol Endod. 2007 May;103(5):e16-20. Pubmed PMID: 17331753

[6]. Ching D, Finkelman M, Loo CY. Effect of the DentalVibe injection system on pain during local anesthesia injections in adolescent patients. Pediatr. Dent. 2014 Jan 15;36(1):51-5.

[7]. Kanaa MD, Meechan JG, Corbett IP, Whitworth JM. Speed of injection influences efficacy of inferior alveolar nerve blocks: a double-blind randomized controlled trial in volunteers. J. Endod. 2006 Oct 1;32(10):919-23.

[8]. Govindaraju L, Gurunathan D. Effectiveness of Chewable Tooth Brush in Children-A Prospective Clinical Study. J Clin Diagn Res. 2017 Mar;11(3):ZC31-ZC34.Pubmed PMID: 28511505.

[9]. Christabel A, Anantanarayanan P, Subash P, Soh CL, Ramanathan M, Muthusekhar MR, et al. Comparison of pterygomaxillary dysjunction with tuberosity separation in isolated Le Fort I osteotomies: a prospective, multi-centre, triple-blind, randomized controlled trial. Int J Oral Maxillofac Surg. 2016 Feb;45(2):180-5.Pubmed PMID: 26338075.

[10]. Soh CL, Narayanan V. Quality of life assessment in patients with dentofacial deformity undergoing orthognathic surgery--a systematic review. Int J Oral Maxillofac Surg. 2013 Aug;42(8):974-80.Pubmed PMID: 23702370.

[11]. Mehta M, Deeksha, Tewari D, Gupta G, Awasthi R, Singh H, et al. Oligonucleotide therapy: An emerging focus area for drug delivery in chronic inflammatory respiratory diseases. Chem Biol Interact. 2019 Aug 1;308:206215.Pubmed PMID: 31136735

[12]. Ezhilarasan D, Apoorva VS, Ashok Vardhan N. Syzygium cumini extract induced reactive oxygen species-mediated apoptosis in human oral squa- mous carcinoma cells. J Oral Pathol Med. 2019 Feb;48(2):115-121.Pubmed PMID: 30451321

[13]. Campeau PM, Kasperaviciute D, Lu JT, Burrage LC, Kim C, Hori M, et al. The genetic basis of DOORS syndrome: an exome-sequencing study. Lancet Neurol. 2014 Jan;13(1):44-58.Pubmed PMID: 24291220.

[14]. Sneha S. Knowledge and awareness regarding antibiotic prophylaxis for infective endocarditis among undergraduate dental students. Asian J Pharm Clin Res. 2016 Oct 1:154-9.

[15]. Christabel SL, Linda Christabel S. Prevalence of type of frenal attachment and morphology of frenum in children, Chennai, Tamil Nadu. World J Dent. 2015 Oct;6(4):203-7.

[16]. Kumar S, Rahman R. Knowledge, awareness, and practices regarding biomedical waste management among undergraduate dental students. Asian J Pharm Clin Res. 2017;10(8):341.

[17]. Sridharan G, Ramani P, Patankar S. Serum metabolomics in oral leukoplakia and oral squamous cell carcinoma. J Cancer Res Ther. 2017 Jul 1;13(3):55661.

[18]. Ramesh A, Varghese SS, Doraiswamy JN, Malaiappan S. Herbs as an antioxidant arsenal for periodontal diseases. J Intercult Ethnopharmacol. 2016 Jan 27;5(1):92-6.Pubmed PMID: 27069730.

[19]. Thamaraiselvan M, Elavarasu S, Thangakumaran S, Gadagi JS, Arthie T. Comparative clinical evaluation of coronally advanced flap with or without platelet rich fibrin membrane in the treatment of isolated gingival recession. J Indian Soc Periodontol. 2015 Jan;19(1):66-71.

[20]. Thangaraj SV, Shyamsundar V, Krishnamurthy A, Ramani P, Ganesan K, Muthuswami M, et al. Molecular Portrait of Oral Tongue Squamous Cell Carcinoma Shown by Integrative Meta-Analysis of Expression Profiles with Validations. PLoS One. 2016 Jun 9;11(6):e0156582.Pubmed PMID: 27280700 .

[21]. Ponnulakshmi R, Shyamaladevi B, Vijayalakshmi P, Selvaraj J. In silico and in vivo analysis to identify the antidiabetic activity of beta sitosterol in adipose tissue of high fat diet and sucrose induced type-2 diabetic experimental rats. Toxicol Mech Methods. 2019 May;29(4):276-290.Pubmed PMID: 30461321.

[22]. Ramakrishnan M, Shukri M. Fluoride, Fluoridated Toothpaste Efficacy And Its Safety In Children-Review. Int. J. Pharm. Res. 2018 Oct 1;10(04):10914.

[23]. Chan HH, Lam LK, Wong DS, Wei WI. Role of skin cooling in improving patient tolerability of Q-switched Alexandrite (QS Alex) laser in nevus of Ota treatment. Lasers Surg Med. 2003;32(2):148-51.Pubmed PMID: 12561049.

[24]. Leff DR, Nortley M, Dang V, Bhutiani RP. The effect of local cooling on pain perception during infiltration of local anaesthetic agents, a prospective randomised controlled trial. Anaesthesia. 2007 Jul;62(7):677-82.Pubmed PMID: 17567343

[25]. Kuwahara RT, Skinner Jr RB. EMLA versus ice as a topical anesthetic. Dermatol Surg. 2001 May;27(5):495-6.

[26]. Kosaraju A, Vandewalle KS. A comparison of a refrigerant and a topical anesthetic gel as preinjection anesthetics: a clinical evaluation. J Am Dent Assoc. 2009 Jan;140(1):68-72.Pubmed PMID: 19119169.

[27]. Aminabadi NA, Farahani RM. The effect of pre-cooling the injection site on pediatric pain perception during the administration of local anesthesia. J Contemp Dent Pract. 2009 May 1;10(3):43-50.Pubmed PMID: 19430625.

[28]. Long RR. Cold fiber heat sensitivity: dependency of 'paradoxical'discharge on body temperature. Brain Res. 1973 Dec 7;63:389-92.

[29]. Haghighat A, Davoudi A, Minaiyan M, Molai M, Afshar A, Basiri K. Effect of a trial pharmaceutical solution on reversing sensations after using lidocain: An animal study. Anesth Essays Res. 2015 Jan-Apr;9(1):79-82.Pubmed PMID: 25886425

[30]. Yağiz On A. Cold applications for the treatment of pain. Agri. 2006 Apr;18(2):5-14

[31]. Vijayashree Priyadharsini J. In silico validation of the non-antibiotic drugs acetaminophen and ibuprofen as antibacterial agents against red complex pathogens. J Periodontol. 2019 Dec;90(12):1441-1448.Pubmed PMID: 31257588.

[32]. Pc J, Marimuthu T, Devadoss P, Kumar SM. Prevalence and measurement of anterior loop of the mandibular canal using CBCT: A cross sectional study. Clin Implant Dent Relat Res. 2018 Apr 6;20(4):531-4.

[33]. Ramesh A, Varghese S, Jayakumar ND, Malaiappan S. Comparative estimation of sulfiredoxin levels between chronic periodontitis and healthy patients - A case-control study. J Periodontol. 2018 Oct;89(10):1241-1248.Pubmed PMID: 30044495.

[34]. Ramadurai N, Gurunathan D, Samuel AV, Subramanian E, Rodrigues SJ. Effectiveness of 2\% Articaine as an anesthetic agent in children: randomized controlled trial. Clin Oral Investig. 2019 Sep;23(9):3543-50.

[35]. Sridharan G, Ramani P, Patankar S, Vijayaraghavan R. Evaluation of salivary metabolomics in oral leukoplakia and oral squamous cell carcinoma. J Oral 
Pathol Med. 2019 Apr;48(4):299-306.

[36]. Ezhilarasan D, Apoorva VS, Ashok Vardhan N. Syzygium cumini extract induced reactive oxygen species-mediated apoptosis in human oral squamous carcinoma cells. J Oral Pathol Med. 2019 Feb;48(2):115-121.Pubmed PMID: 30451321.

[37]. Mathew MG, Samuel SR, Soni AJ, Roopa KB. Evaluation of adhesion of Streptococcus mutans, plaque accumulation on zirconia and stainless steel crowns, and surrounding gingival inflammation in primary molars: randomized controlled trial. Clin Oral Investig. 2020 Sep;24(9):1-6.Pubmed PMID: 31955271.
[38]. Samuel SR. Can 5-year-olds sensibly self-report the impact of developmental enamel defects on their quality of life? Int J Paediatr Dent. 2021 Mar;31(2):285-286.Pubmed PMID: 32416620.

[39]. Chandrasekar R, Chandrasekhar S, Sundari KKS, Ravi P. Development and validation of a formula for objective assessment of cervical vertebral bone age. Prog Orthod. 2020 Oct 12;21(1):38.Pubmed PMID: 33043408.

[40]. Vijayashree Priyadharsini J, Smiline Girija AS, Paramasivam A. In silico analysis of virulence genes in an emerging dental pathogen A. baumannii and related species. Arch Oral Biol. 2018 Oct;94:93-98.Pubmed PMID: 30015217. 